\title{
Higher Preoperative Endometrial Cancer Risk Showed more Advanced Stage
}

\author{
Risiko Kanker Endometrium yang lebih Tinggi \\ Menunjukkan Stadium yang lebih Lanjut
}

\author{
Jasmine Iskandar, Gregorius Tanamas, Tofan W. Utami, \\ Tricia D. Anggraeni, Kartiwa H. Nuryanto \\ Division of Oncology Gynecology \\ Department of Obstetrics and Gynecology \\ Faculty of Medicine University of Indonesia/ \\ Dr. Cipto Mangunkusumo Hospital \\ Jakarta
}

\begin{abstract}
Objective: To evaluate the preoperative endometrial cancer risk as a guidance to choose the type of surgical approach based on European Society for Medical Oncology guideline (2009).

Method: Cross-sectional study involved 73 endometrial cancer patients of Dr. Cipto Mangunkusumo Hospital, from January 2006 to December 2012 which obtained from medical record. The inclusion criteria were endometrial cancer patients with complete D\&C, ultrasonographic, and postoperative histopathological reports. Endometrial cancer risk of recurrence was classified according to ESMO 2009 and final diagnosis and stage based on FIGO.
\end{abstract}

Result: From 405 patients, only 73 patients had complete reports. Most of the them were postmenopausal (54.8\%), non-nulliparity (79.9\%), and obese (49.5\%) women. According to risk of recurrence stratification, low, intermediate and high risk were found in 12 patients, 27 patients, and 34 patients. Based on FIGO, there were $60.2 \%$ early and $39.8 \%$ advanced stage. In high risk group, rates of advanced stage were prominent compared to other groups. There were $38.3 \%$ patients with postoperative positive lymph nodes metastases.

Conclusion: Most of the endometrial cancer patients were preoperatively diagnosed as high risk. The commonest stage after surgical examination were IIIC. High risk of recurrence showed more positive lymph node compared to low or intermediate risk. Result of preoperative histopathological and myometrial invasion compared to postoperative results were showed to be inconsistent. Patients with $\geq 1 / 2$ myometrial invasion had more positive lymph nodes metastases. Endometrial cancer risks compared to FIGO stage showed the higher the risk, the more advanced the stage were.

[Indones J Obstet Gynecol 2014; 2: 99-105]

Keywords: endometrial cancer, FIGO stage, high risk, histological type, intermediate risk, low risk, lymph node.

\begin{abstract}
Abstrak
Tujuan: Untuk mengevaluasi risiko kanker endometrium berdasarkan klasifikasi European Society for Medical Oncology (2009) dengan hasil pemeriksaan histopatologi pascaoperatif.

Metode: Studi potong lintang dengan 73 pasien kanker endometrium di Rumah Sakit Dr. Cipto Mangunkusumo dari Januari 2006 sampai Desember 2012 yang didapat dari rekam medis. Kriteria inklusi terdiri dari pasien kanker endometrium yang mempunyai hasil histopatologi dilatasi dan kuretase dan ultrasonografi praoperatif, dan histopatologi pascaoperatif yang lengkap. Klasifikasi risiko rekurensi kanker endometrium berdasarkan ESMO 2009 dan diagnosis stadium akhir berdasarkan FIGO.

Hasil: Dari 405 pasien, hanya 73 pasien yang memiliki data lengkap. Sebagian besar pasien pascamenopause $(54,8 \%)$, bukan nuliparitas $(79,9 \%)$, dan pasien obesitas $(49,5 \%)$. Berdasarkan stratifikasi risiko rekurensi, terdapat 12 pasien risiko rendah, 27 pasien risiko menengah, dan risiko tinggi 34 pasien. Berdasarkan kriteria FIGO, terdapat 60,2\% stadium awal dan 39,8\% stadium menengah. Pada kelompok pasien risiko tinggi, stadium akhir sangat menonjol dibandingkan kelompok risiko lain. Terdapat 38,3\% pasien dengan metastasis positif pada kelenjar getah bening.
\end{abstract}

Kesimpulan: Kebanyakan pasien kanker endometrium didiagnosa risiko tinggi. Stadium IIIC paling sering ditemukan setelah pemeriksaan pascaoperatif. Risiko rekurensi tinggi menunjukkan lebih banyak kelenjar getah bening yang positif dibandingkan risiko rendah ataupun menengah. Hasil histopatologi dan invasi miometrium praoperatif lebih inkonsisten dibandingkan hasil pascaoperatif. Metastasis kelenjar getah bening lebih banyak ditemukan pada pasien dengan invasi $\geq 1 / 2$ miometrium. Semakin tinggi risiko kanker endometrium, semakin lanjut stadiumnya.

[Maj Obstet Ginekol Indones 2014; 2: 99-105]

Kata kunci: kanker endometrium, kelenjar getah bening, risiko menengah, risiko rendah, risiko tinggi, stadium FIGO, tipe histologi.

Correspondence: Jasmine Iskandar. Department of Obstetrics and Gynecology. Faculty of Medicine University of Indonesia, Jakarta. Telephone: 08176040205. Email: iskandarjasminee@gmail.com

\section{INTRODUCTION}

Endometrial cancer is the sixth most common cancer in women worldwide, with an estimated 288,387 new cases in 2008, and a standardized incidence rate of 8.2 per 100,000 women. While the global burden, in terms of the number of cases, is evenly distributed between less developed and more developed regions, incidence and mortality rates are higher in more developed regions. ${ }^{1}$

North America and Western Europe show some of the highest standardized incidence rates (greater than 10 per 100,000 women), with the lowest 
rates occurring in Asia and Africa. ${ }^{2}$ Overall, the mortality incidence ratio of endometrial cancer is $26 \%$, and it was responsible for 73,854 deaths in 2008. ${ }^{1}$ This cancer rise sharply in occurrence during the perimenopausal years and peak well after the menopause. ${ }^{3}$ Ninety percent of cases occur in women older than 50 years, and the median age at diagnosis is 62 years. $^{1-4}$ Most women are being diagnosed because of irregular vaginal bleeding and roughly $76 \%$ of women survive for 5 years. ${ }^{5}$

Diagnosis of endometrial cancer is confirmed by endometrial biopsy via dilatation and curettage (D\&C). ${ }^{5}$ A diagnosis of endometrial cancer must be obtained before staging or treatment that confirms the cancer, identifies the histological type and grade. ${ }^{5,6}$ Treatment strategy is determined by classifed risk of recurrence, which is defined by stage, histological type, and grade according to European Society for Medical Oncology (ESMO) risk classification 2009. Surgery is the standard treatment for endometrial cancer patient. Others additional operative procedures, such as lymphadenectomy and/ or omentectomy are performed based on clinical stage, histological type, and grade..$^{5-7}$

Based on histopathology, endometrial cancer is divided into two categories, type I is endometrioid tumors which suggested that the multistep carcinogenicprocess of type 1 endometrial tumors begins with simple endometrial hyperplasia, progresses to complex atypia hyperplasia, and then develops into the precursor lesion, endometrial intraepithelial neoplasia (EIN). Type 2 or nonendometrioid tumors, encompasses the remaining $10-20 \%$ of sporadic endometrial tumors. Histologies of type 2 are uterine papillary serous carcinoma (UPSC), clearcell carcinoma and carcinosarcoma. ${ }^{5,8}$

Myometrial invasion depth is a predictor of recurrence, and important in the decision making for adjuvant treatment. ${ }^{9,10}$ According to the FIGO staging system, myometrial invasion depth is expressed as invasion of $<1 / 2$ of the myometrium and $\geq 1 / 2$ of the myometrium. ${ }^{9,11}$ Preoperative radiologic testing using ultrasound, computed tomography, or magnetic resonance imaging is suboptimal in identifying patients with pelvic or paraaortic nodal metastases and to examine myometrial invasion. ${ }^{12,13}$

Patients with low risk endometrial cancers or intra operatively assessed with no lymph node metastases are not considered for pelvic and para-aortic lymphadenectomy for surgical staging.14,15 Meanwhile, in intermediate risk patient, the use- fulness of lymphadenectomy is still debating, and pelvic lymphadenectomy is not recommended, unless for stage IB grade 2 or stage IA grade 3 with myometrial involvement. ${ }^{5}$ Para-aortic and iliac lymphadenectomy is recommended in high risk endometrial cancers. ${ }^{5}$

The objective of this study is to evaluate preoperative endometrial cancer risk of recurrence, based on dilatation and curettage (D\&C) histopathological and ultrasonographic findings, to their postoperative histopathological findings.

\section{METHODS}

This retrospective study was conducted on endometrial cancer patients in Dr. Cipto Mangunkusumo General Hospital, Jakarta, Indonesia from January 2006 until December 2012. Patients' data were obtained from medical record consisting age, menopausal status, parity, BMI status, preoperative and postoperative histopathological reports, and ultrasonographic reports. The inclusion criteria of this study were endometrial cancer patients with dilatation and curettage (D\&C) histopathological reports, ultrasonographic examination, and postoperative histopathological reports. Patients with incomplete histopathological result were excluded from this study.

BMI status $\left(\mathrm{kg} / \mathrm{m}^{2}\right)$ was defined based on World Health Organization (WHO) for Asian population classification. ${ }^{16}$ Endometrial cancer risk of recurrence was classified into low, intermediate, and high risk according to European Society for Medical Oncology (ESMO) 2009, based on histological type, grade, and myometrial invasion. ${ }^{7}$ Preoperative histological type and grade were obtained by D\&C histopathological reports. Meanwhile, myometrial invasion depth was obtained by ultrasonographic examination. Endometrial cancer was stage based on Federation of Gynecology and Obstetrics (FIGO) 2009 endometrial cancer surgical staging. 5

Lymphadenectomy was recommended in high risk endometrial cancer. ${ }^{5}$ Lymphadenectomy is recommended for intermediate risk, but this can be considered stage IB grade 2 and stage IA grade 3 with myometrial involvement. Meanwhile, lymphadenectomy is not recommended in low risk endometrial cancer.

All data were processed with SPSS 20.0 software. The statistical analysis used was a descriptive study of D\&C histopathological findings, ultra- 
sonographic examination, and postoperative histopathological result.

\section{RESULT}

From 405 patients identified from hospital registry from January 2002 until December 2012, only 73 of them had complete D\&C histopathological reports, ultrasonographic reports, and postoperative histopathological reports.

Demographic characteristics of patients was shown in Table 1. Patients' age ranges from 34 to 79 years old. There were 40 menopausal patients $(54.7 \%)$ whose age ranges from 41 to 58 years old, and 33 premenopausal patients $(45.3 \%)$ whose age ranges from 34 to 40 years old. Patient's parity range from 0 to 10 parities, with mean parity was 3 parities. Regarding body mass index, there were 5 underweight patients (6.8\%), 22 normal patients (30.1\%), 10 overweight patients (13.6\%), 24 obese grade I patients $(32.8 \%)$ and 12 obese grade II patients $(16.7 \%)$.

Table 1. Distribution of Endometrial Cancer in Dr. Cipto Mangunkusumo Hospital year 2002-2012.

\begin{tabular}{lcc}
\hline \hline \multicolumn{1}{c}{ Demographic Characteristics } & $\mathbf{n}=\mathbf{7 3}$ & \% \\
\hline Age & & \\
- Median & 53 & \\
- Minimum & 34 & \\
- Maximum & 79 & \\
Parities & & \\
- Mean & 3 & \\
- Minimum & 0 & \\
- Maximum & 10 & \\
- Nulliparity & 22 & 30.1 \\
Menopause & & \\
- Yes & 40 & 54.8 \\
- No & 33 & 45.2 \\
Menopausal Age & & \\
- Median & 51 & \\
- Minimum & & \\
- Maximum & 41 & \\
Body Mass Index & 58 & \\
- Underweight & & \\
- Normal & & \\
- Overweight & 52.8 \\
- Obese I & & \\
- Obese II & & \\
\hline
\end{tabular}

The distribution of endometrial cancer risk or recurrence is based on histological type, grade, and myometrial invasion depth according to ESMO 2009 guidelines.There were low, intermediate and high risk..$^{5}$ In this research, low risk found in 12 patients $(16.4 \%)$, intermediate risk in 27 patients (36.9\%), and high risk 34 patients (46.7\%).

Either from D\&C or postoperative histopathological findings showed that Endometrioid Adenocarcinoma was the most detected histological type from, 62 patients and 60 patients $(84.9 \%$ and 82.1\%). From 62 Endometrioid Adenocarcinoma $(84.9 \%)$ assessed from D\&C, there were 6 patients (9.6\%) which had different final histological type result. The other D\&C histological types showed no different findings referred to postoperative histological types. (Table 2) Endometrial cancer grade, based on D\&C histopathological reports, was evenly distributed. But, when it comes from postoperative histopathological reports, grade II was the commonest found (42.4\%).

From 73 patients assessed by ultrasonography examination, showed 23 patients $(31.5 \%)$ with < $1 / 2$ myometrial invasion and 50 patients $(68.5 \%)$ with $\geq 1 / 2$ myometrial invasion. There were 27 patients $(36.9 \%)$ identified by postoperative pathological finding showed different myometrial invasion result compared to ultrasonography examination.

Lymph node of $<1 / 2$ myometrial invasion (based on ultrasonographic) was evaluated in 12 patients (52.1\%), and only 7 patients (58.3\%) with positive lymph nodes metastases, and 11 patients $(47.9 \%)$ without evaluation of lymph node because lymphadenectomy was not performed in these patients. Group with $\geq 1 \frac{1}{2}$ myometrial invasion had 39 patients (78\%) with lymphadenectomy, and 22 patients $(44 \%)$ of them had positive lymph node metastases. Eleven patients $(22 \%)$ were not performed lymphadenectomy.

From 12 patients with low endometrial cancer risk that underwent surgery, 3 patients (25\%) had lymphadenectomy with negative pathological results. Seven out $(25.5 \%)$ of 27 patients with intermediate risk were not performed lymphadenectomy. The rest 20 patients of intermediate risk with lymphadenectomy showed 7 patients (35\%) had negative lymph node metastases and 13 patients $(65 \%)$ had positive lymph node metastases. Meanwhile, patients with high risk endometrial cancer showed 20 patients $(58.8 \%)$ positive lymph node metastases. 
Table 2. Histological Type Comparison between D\&C Histological Type and Operative Histological Type.

\begin{tabular}{|c|c|c|c|c|c|c|}
\hline \multirow{2}{*}{$\begin{array}{l}\text { D\&C Histolo- } \\
\text { gical Type }\end{array}$} & \multicolumn{5}{|c|}{ Operative Histological Type } & \multirow{2}{*}{ Total } \\
\hline & $\begin{array}{c}\text { Endometrioid } \\
\text { Adenocarcinoma }\end{array}$ & $\begin{array}{l}\text { Adenosquamous } \\
\text { Carcinoma }\end{array}$ & $\begin{array}{l}\text { Papillary Squa- } \\
\text { mous Carcinoma }\end{array}$ & $\begin{array}{c}\text { Clear Cell } \\
\text { Carcinoma }\end{array}$ & $\begin{array}{l}\text { Carcino- } \\
\text { sarcoma }\end{array}$ & \\
\hline $\begin{array}{l}\text { Endometrioid } \\
\text { Adenocarcinoma }\end{array}$ & 56 & 1 & 2 & 1 & 2 & 62 \\
\hline $\begin{array}{l}\text { Adenosquamous } \\
\text { Carcinoma }\end{array}$ & 0 & 1 & 0 & 0 & 0 & 1 \\
\hline $\begin{array}{l}\text { Papillary Squa- } \\
\text { mous Carcinoma }\end{array}$ & 4 & 0 & 2 & 0 & 0 & 6 \\
\hline $\begin{array}{l}\text { Clear Cell } \\
\text { Carcinoma }\end{array}$ & 0 & 0 & 0 & 2 & 0 & 2 \\
\hline Carcinosarcoma & 0 & 0 & 0 & 0 & 2 & 2 \\
\hline Total & 60 & 2 & 4 & 3 & 4 & 73 \\
\hline
\end{tabular}

Table 3. Risk of Endometrial Cancer Compared to FIGO Stage.

\begin{tabular}{lccccccccc}
\hline \hline \multirow{2}{*}{ Risk } & \multicolumn{10}{c}{ FIGO Stage } & & & Total \\
\cline { 2 - 11 } & Stage IA & Stage IB & Stage II & Stage IIIA & Stage IIIB & Stage IIIC & Stage IVA & Stage IVB & 0 \\
\hline Low & 2 & 6 & 3 & 1 & 0 & 0 & 0 & 0 & 12 \\
Intermediate & 4 & 9 & 1 & 5 & 0 & 8 & 0 & 0 & 27 \\
High & 2 & 6 & 4 & 1 & 0 & 18 & 1 & 2 & 34 \\
\hline Total & 8 & 21 & 8 & 7 & 0 & 26 & 1 & 2 & 73 \\
\hline \hline
\end{tabular}

There were $41.67 \%$ of low risk endometrial cancer patients, $25.93 \%$ of intermediate risk endometrial cancer patients, and $29.41 \%$ of high risk endometrial cancer patients who had $<1 / 2$ myometrial invasion. Whereas $58.33 \%$ of low risk patients, $74.07 \%$ of intermediate risk patients, and $69.86 \%$ high risk patients had $\geq 1 / 2$ myometrial invasion.

Low risk endometrial cancer was found $66.6 \%$ confined to uterus. Intermediate risk was found $48.1 \%$ confined to uterus and $29.6 \%$ metastasize to pelvic and/or paraaorta lymph nodes. Meanwhile, high risk was found $26.4 \%$ confined to uterus and $50 \%$ metastasize to pelvic and/or paraaorta lymph nodes. All the low risk endometrial cancer patients' histological type were Endometrioid Adenocarcinoma based on postoperative histopathological finding. Endometrioid Adenocarcinoma was the commonest histological type found in intermediate and high risk endometrial cancer.

From 12 patients with low risk endometrial cancer, there were 11 patients $(91.6 \%)$ identified with early stage and 1 patient (8.4\%) with advanced stage endometrial cancer. In intermediate risk group, there were 14 patients (51.8\%) with early stage and 13 patients (48.2\%) with advanced stage. From high risk group, 12 patients (35.2\%) with early stage and 22 patients $(64.8 \%)$ with advanced stage. (Table 3)

\section{DISCUSSION}

Endometrial cancer is the most common gynecological cancer affecting postmenopausal women. Endometrial cancer most commonly affects women between 50 - 65 years old. ${ }^{3,17}$ Those reports were consistent with our study. However, the difference between postmenopausal women (54.8\%) and premenopausal women (45.2\%) in our study is not prominent. Menstrual factors, early age at menarche and late age at menopause, contribute for development of endometrial cancer. ${ }^{3}$ In this study age at menarche was not observed, because of lack information regarding patient's menarche, especially data from postmenopausal women group. Patients' 
age in our hospital ranges from 34 - 79 years old, and the median age is 53 years old. Postmenopausal patients' age ranges from 51- 58 years old, and the median is 51 years old. Endometrial cancer is rare before 40 years old, and in this study only 5 patients under 40 years old were found. ${ }^{3}$

The other risk factor contributing to endometrial cancer is nulliparity which in our study accounted for $30.1 \%$ of all patients. ${ }^{3,17}$ Patients' parity ranges from 0 to 10 parities and the mean value is 3 parities. Nulliparity increase the rate the risk of endometrial cancer two to three times compared with non-nulliparity group, and also the risk is decreasing with increasing number of children. Infertility also associated with increasing risk of endometrial cancer, such as polycystic ovary syndrome. $^{3}$

Several studies reported that endometrial cancer is associated with obesity. Obesity increases endometrial cancer risk 3-fold independently compared to non-obese women. ${ }^{18}$ Central or upperbody is more important the measurement pheral body adiposity specially measurement of central adiposity after adjustment of BMI, to measure risk of endometrial cancer.,19-21 In our report, obese women (BMI $\geq 25 \mathrm{~kg} / \mathrm{m}^{2}$ ) accounted for $39.5 \%$ of all patients which consist of $32.8 \%$ obese grade 1 (BMI $25-29.9 \mathrm{~kg} / \mathrm{m}^{2}$ ) and $16.7 \%$ obese grade 2 $\left(B M I \geq 30 \mathrm{~kg} / \mathrm{m}^{2}\right)$. The distribution of endometrial cancer in normal BMI $\left(18.5-24.9 \mathrm{~kg} / \mathrm{m}^{2}\right)$ patient was $30.1 \%$ which was not much different in number with obese grade I patient. Obesity associated with increasing of endometrial cancer could be biologically explained. Postmenopausal obese women have higher endogenous level of estrogen compared to lean women due to amortization of androstenedione in adipose tissue. ${ }^{3,18}$

Based on histopathological finding, approximately $80 \%$ of endometrial cancer were type I (endometrioid) with well to moderate differentiation which were confined to the uterine corpus at diagnosis. High grade type II endometrial cancer accounted for only $15 \%$ to $20 \%$ of cases. ${ }^{8}$ In our study, endometrial cancer type I accounted for 82.1\% cases based on D\&C results, and 84.9\% based on histopathological finding. There were 9.6\% patients diagnosed with endometrial cancer type I based on D\&C result had different postoperative histopathological result. It indicates the D\&C examination in our hospital is reliable to determine endometrial cancer histological type.
Meanwhile, differentiation of endometrial cancer based on postoperative histopathological result shows $50.6 \%$ discrepancy compared to D\&C result. We found that poor differentiation based on D\&C result had the most discrepancy (56.5\%) compare to other differentiation.

Myometrial invasion preoperative assessment based on ultrasonographic findings is used for determining endometrial cancer risk and planning surgical procedures. ${ }^{10,22}$ Our study collected $<1 / 2$ myometrial invasion based on ultrasonography findings had $60.8 \%$ discrepancy compared to postoperative histopathological finding. Meanwhile, $\geq$ $1 / 2$ myometrial invasion based on ultrasonography had 26\% discrepancy. Our finding is consistent with study conducted by Sato et al, preoperative myometrial invasion depth based on ultrasonography gives inconsistent result compared to postoperative histopathological finding. ${ }^{22}$

Myometrial invasion depth helps clinicians make decisions during operation to do or not to do lymphadenectomy. ${ }^{12,14,23}$ According to our finding, in $\geq 1 / 2$ myometrial invasion group (based on ultrasonographic examination), only $78 \%$ cases were performed lymphadenectomy procedure. Meanwhile, in $<1 / 2$ myometrial invasion (postoperative histopathological finding) group, lymphadenectomy was performed in $52.1 \%$ cases. It showed lymphadenectomy is performed not only based on myometrial invasion depth, but also based on intraoperative assessment of suspicious enlarged lymphnode.

Endometrial cancer risk were determined by histological type, grade and myometrial invasion according to European Society for Medical Oncology (ESMO) 2009. ${ }^{5}$ This risk classification aim to determine recurrence, additional procedures (lymphadenectomy and/or omentectomy), and adjuvant therapy. ${ }^{5}$ There were $16.4 \%$ low risk, $37.9 \%$ intermediate risk and $45.7 \%$ high risk patients. Compared to surgical staging, low risk patients had been confirmed as early stage for $91.6 \%$ and as advanced stage for $8.4 \%$. Intermediate risk cancer had been confirmed as early stage for $51.8 \%$ and as advanced stage for $48.2 \%$. High risk cancer had been confirmed as early stage for $35.2 \%$ and as advanced stage for $64.8 \%$.

Based on postoperative histopathological result, all low risk endometrial cancer patients showed type I (endometrioid adenocarcinoma) findings, $11.1 \%$ of intermediate risk endometrial cancer pa- 
tients showed type II histological findings, and $29.4 \%$ of high risk endometrial cancer patients showed type II histological findings.

Querleu et al, recommends lymphadenectomy is performed in high risk endometrial cancer, and in intermediate risk if the tumor in stage IB grade 2 or IA grade 3 with myometrial involvement. Lymphadenectomy is not recommended in low risk endometrial cancer. ${ }^{5}$ In our study, $75 \%$ of low risk endometrial cancer patients' lymph nodes was not assessed. Only $25 \%$ of them were assessed because of intraoperative assessment of suspicious enlarged lymph node. However, the lymph node pathological assessment returned with negative result. Intermediate risk endometrial cancer patient underwent pelvic and/or paraaorta lymphadenectomy for $74 \%$ cases, only $40 \%$ of all the patients had positive lymph node metastases. From $82.3 \%$ high risk patients underwent pelvic and/or paraaorta lymphadenectomy, $58.8 \%$ had positive lymph node metastases. According to this finding, high risk endometrial cancer patient had the most positive lymph node result compared to other risks. Moreover, increasing risk classification showed more positive lymph node metastases.

Most of the patients were finally diagnosed with Stage IIIC (35.6\%) endometrial cancer. However, most of the patients were diagnosed with early stage endometrial cancer (50.6\%). Endometrial cancer risks compared to FIGO stage showed the higher the risk patient had, the more advanced the stage were.

\section{CONCLUSION}

Most of the patients with endometrial cancer were preoperatively diagnosed as high risk group. The commonest of the stage after surgical histopathological examination were stage IIIC. High risk of recurrence endometrial cancer showed more positive lymph node compared to low or intermediate risk of recurrence. Histopathological findings based on D\&C examination showed inconsistent results compared to postoperative histopathological findings. Myometrial invasion findings based on ultrasonography compared to postoperative findings showed inconsistent results. Patients with $\geq 1 / 2$ myometrial invasion had more positive lymph nodes metastases compared to $<1 / 2$ myometrial invasion. Endometrial cancer risks compared to FIGO stage showed the higher the risk patient had, the more advanced the stage were.

\section{REFERENCES}

1. Weiderpass E, Labreche F. Malignant tumors of the female reproductive system. Saf Health Work 2012; 3(3): 166-80.

2. Merritt MA, Cramer DW. Molecular pathogenesis of endometrial and ovarian cancer. Cancer Biomark 2010; 9(1-6): 287-305.

3. Purdie DM. Epidemiology of endometrial cancer. Reviews in Gynaecological Practice 2003; 3(4): 217-20.

4. Cramer DW. The epidemiology of endometrial and ovarian cancer. Hematol Oncol Clin North Am 2012; 26(1): 1-12.

5. Querleu D, Planchamp F, Narducci F, et al. Clinical practice guidelines for the management of patients with endometrial cancer in France: recommendations of the Institut National du Cancer and the Societe Francaise d'Oncologie Gynecologique. Int J Gynecol Cancer 2011; 21(5): 945-50.

6. Kirby TO, Leath CA, $3^{\text {rd }}$, Kilgore LC. Surgical staging in endometrial cancer. Oncology (Williston Park) 2006; 20(1): 45-50; discussion, 3-4, 63.

7. Uccella S, Kohler C. Endometrial cancer. Textbook of gynaecological onkology. $2^{\text {nd }}$ ed. Turkey: Gunes Publishing; 2010.

8. Prat J. Prognostic parameters of endometrial carcinoma. Hum Pathol 2004; 35(6): 649-62.

9. Geels YP, Pijnenborg JMA, van den Berg-van Erp SHM, Snijders MPML, Bulten J, Massuger LFAG. Absolute depth of myometrial invasion in endometrial cancer is superior to the currently used cut-off value of 50\%. Gynecol Oncol 2013; 129(2): 285-91.

10. Kanat-Pektas M, Gungor T, Mollamahmutoglu L. The evaluation of endometrial tumors by transvaginal and Doppler ultrasonography. Arch Gynecol Obstet 2008; 277(6): 495-9.

11. Hi DS, Barakat RR, Palayekar MJ, et al. The incidence of pelvic lymph node metastases by FIGO staging for patients with adequately surgically staged endometrial adenocarcinoma of endometrioid histology. Int J Gynecol Cancer 2008; 18(2): 269-73.

12. Morales Olaya FJ, Dualde D, Garcia E, et al. Transvaginal sonography in endometrial carcinoma: preoperative assessment of the depth of myometrial invasion in 50 cases. Eur J Radiol 1998; 26(3): 274-9.

13. Bidus MA, Risinger JI, Chandramouli GV, et al. Prediction of lymph node metastases in patients with endometrioid endometrial cancer using expression microarray. Clin Cancer Res 2006; 12(1): 83-8.

14. Lee KB, Ki KD, Lee JM, et al. The risk of lymph node metastases based on myometrial invasion and tumor grade in endometrioid uterine cancers: a multicenter, retrospective Korean study. Ann Surg Oncol 2009; 16(10): 2882-7.

15. Neubauer NL, Lurain JR. The role of lymphadenectomy in surgical staging of endometrial cancer. Int J Surg Oncol 2011: 8146-9.

16. Appropriate body-mass index for Asian populations and its implications for policy and intervention strategies. Lancet 2004; 363(9403): 157-63.

17. National Guideline C. Management of endometrial cancer. http://www.guidelines.gov/content.aspx?id=10930 (accessed 5/3/2013.

18. Park SL, Goodman MT, Zhang ZF, Kolonel LN, Henderson BE, Setiawan VW. Body size, adult BMI gain and endometrial cancer risk: the multiethnic cohort. Int J Cancer 2010; 126(2): 490-9. 
19. Nagle CM, Marquart L, Bain CJ, et al. Impact of weight change and weight cycling on risk of different subtypes of endometrial cancer. Eur J Cancer.

20. Wartko P, Sherman ME, Yang HP, Felix AS, Brinton LA, Trabert B. Recent changes in endometrial cancer trends among menopausal-age US women. Cancer Epidemiol.

21. Purdie DM, Green AC. Epidemiology of endometrial cancer. Best Pract Res Clin Obstet Gynecol 2001; 15(3): 341-54.
22. Sato S, Itamochi H, Shimada M, et al. Preoperative and intraoperative assessments of depth of myometrial invasion in endometrial cancer. Int J Gynecol Cancer 2009; 19(5): 884-7.

23. Fotiou S, Vlahos N, Kondi-Pafiti A, Zarganis P, Papakonstantinou K, Creatsas G. Intraoperative gross assessment of myometrial invasion and cervical involvement in endometrial cancer: Role of tumor grade and size. Gynecol Oncol 2009; 112(3): 517-20. 